\title{
Modern Authors in New England College Libraries
}

\begin{abstract}
Librarians, Friends, and others interested in contemporary and near-contemporary authors will find below information as to some existing accumulations of the works of such authors.
\end{abstract}

$\mathrm{F}$ ROM THE THREE SURVEYS published in the Library Quarterly, "Notable Materials Added to American Libraries . . . ," covering the years from I938-4I, we learn that several college and university libraries, especially those at Southern California, Yale, and Dartmouth, have been acquiring first editions of modern American and English authors, some of which may or may not later seem of importance.

It was felt by the writer that a census of such collections might be of value to scholars as well as to libraries not wishing to duplicate holdings in nearby academic institutions. To secure information about these items from all college libraries in the United States, however, would have been in present circumstances an impossible task. It was decided, therefore, to prepare a census covering New England and the authors whose most notable work has appeared in the period since the beginning of World War I. This date was chosen to fit the classification used in the Dartmouth College Library, a classification adopted not long since as best fitting the needs of the English department. As a result of the use of this scheme, descriptions of several collections reported from the colleges are not included here. The names of Katharine
Lee Bates, Kenneth Grahame, Caroline Hazard, Maurice Hewlett, Arthur Machen, George Herbert Palmer, Vida D. Scudder, George Bernard Shaw, Stanley Weyman, Edith Wharton, George Woodberry, and W. B. Yeats are among those omitted.

A questionnaire was sent to thirty of the larger New England college libraries. Replies were received from all but three of these. The libraries were asked to report in each case:

I. Number of printed items

2. Number of manuscripts and typescripts

3. Whether it was a gift or purchase

4. Whether additions were being made

5. Whether it included other material, such as articles about the author, photographs, clippings, and letters.

Answers were also sought to the following questions: Are such collections kept separately or with other rare books or simply located in the stacks? What were the prime reasons for making these collections and what use is being made of them at the present time? The librarians were also asked, if they did not have such holdings, to suggest the names of some modern authors whose works they would be glad to acquire if funds were available. Such data as were submitted and are significant are reported below.

Fifteen of the libraries, i.e., Amherst, Bennington, Boston College, Bowdoin, Clark, Connecticut, Maine, Massachusetts Institute of Technology, New Hampshire, 
Norwich, Simmons, Smith, Trinity, Tufts, and Wesleyan, reported that they had no such collections. One or two felt that it was not in the province of small libraries to gather such material. Others stated that they would be glad to secure it, but were prevented by the lack of funds.

In the libraries that told of holdings, seventy-nine modern American and English writers are being collected. Among authors, Edwin Arlington Robinson leads, with collections in six institutions, and Robert Frost comes second, with material in five institutions, so that these two authors apparently possess rather general appeal. Of the rest, some are collected for special reasons, such as that the authors are graduates of the colleges reporting. Colby has collected the works of five authors primarily because they are Maine people. Mount Holyoke reports that it has laid special emphasis on women writers, and Wellesley, on modern poets. It should be said that Wellesley has begun some collections which are not mentioned in this survey because the number of items represented was considered too small.

\section{Holdings Reported ${ }^{1}$}

Conrad Aiken. Harvard: $88 \mathrm{C}, 18 \mathrm{E},{ }_{3} \mathrm{FK}$; Wellesley: $5 \mathrm{C}$.

Winifred Ashton (Clemence Dane): Mount Holyoke: $20 \mathrm{C}$.

Leonard Bacon. Wellesley: $19 \mathrm{C}, 3 \mathrm{~J}, 2 \mathrm{~L}$.

Enid Bagnold. Mount Holyoke: $5 \mathrm{C}$.

Stephen Vincent Benét. Yale: A, G, K.

William Rose Benét. Wellesley: $9 \mathrm{C}, \mathrm{IE}, \mathrm{IJ}$.

Kay Boyle. Mount Holyoke: 3C.

Gamaliel Bradford. Harvard: $20 \mathrm{C}, 22 \mathrm{H}$,

${ }^{1}$ Explanation of Symbols

A-All published works

B-Collected works

C-Printed items

D-Practically all printed works

E-Manuscripts

F-Volumes of manuscript notes

G-Volumes of manuscript

$\mathrm{H}$-Manuscript notebooks

J-Typescripts

$\mathrm{K}$-Miscellaneous material about author

L-Letters

M-Several magazine articles

$\mathrm{N}$-Corrected proofsheets
$9000 \mathrm{~L}$ (by or about him), 3600 volumes from his library.

Anna Hempstead Branch. Wellesley: ${ }_{5} \mathrm{C}$, $2 \mathrm{E}, 4 \mathrm{~L}$.

Katharine Brush. Mount Holyoke: 8C.

Witter Bynner. Harvard: $45 \mathrm{C},{ }_{2} \mathrm{E}$; Wellesley: $7 \mathrm{C}$.

James Branch Cabell. Yale: A, K.

Erskine Caldwell. Dartmouth: $85 \mathrm{C}$ (including periodical "firsts"), IoJ. Mount Holyoke: $19 \mathrm{C}$.

Willa Cather. Middlebury: $2 \mathrm{IC}, 3 \mathrm{~L} ;$ Mount Holyoke: $\mathrm{B},{ }_{17} \mathrm{C}$.

Robert P. Tristram Coffin. Wellesley: 6C.

Florence Converse. Wellesley: ${ }_{15} \mathrm{C}, 1 \mathrm{E}, 2 \mathrm{~J}$, $6 \mathrm{~L}$.

A. E. Coppard. Yale: $30 \mathrm{C}$.

E. E. Cummings. Harvard: Considerable C and $\mathrm{E}$.

Olive Dargan. Wellesley: $5 \mathrm{C}, 6 \mathrm{~L}$.

Walter de la Mare. Wellesley: $\mathrm{I}_{4} \mathrm{C}, \mathrm{IE}, \mathrm{IL}$.

Clarence Day. Yale: $\mathrm{A}$, many $\mathrm{L}$ and reproductions of $\mathrm{L}$.

John Dos Passos. Mount Holyoke: ${ }_{15} \mathrm{C}$.

Norman Douglas. Dartmouth: $38 \mathrm{C},{ }_{3} \mathrm{E}, \mathrm{IJ}$, $60 \mathrm{~L}$.

T. S. Eliot. Harvard: On deposit, A, many E (some unpublished), $300 \mathrm{~L} ; W$ ellesley: $8 \mathrm{C}$.

William Falkner. Mount Holyoke: 18C.

Rachel Field. Radcliffe: A.

Dorothy Canfield Fisher. Vermont: D.

John Gould Fletcher. Yale: A, H.

Robert Frost. Brown: D; Dartmouth: 29C, ${ }_{5} \mathrm{E},{ }_{5} \mathrm{~L} ;$ Harvard: $3 \mathrm{I} \mathrm{C},{ }_{\mathrm{IE}}$; Middlebury: ${ }_{22} \mathrm{C}, 1 \mathrm{~J}, 7 \mathrm{~L} ;$ Wellesley: $16 \mathrm{C}, 2 \mathrm{E}, 6 \mathrm{~L}$.

Wilfred W. Gibson. Wellesley: $16 \mathrm{C}, 2 \mathrm{~L}$.

Ellen Glasgow. Mount Holyoke: 18C.

Abbie Carter Goodloe. Wellesley: 6C.

Hermann Hagedorn. Wellesley: ${ }_{7} \mathrm{C},{ }_{3} \mathrm{~L}$.

Ernest Hemingway. Mount Holyoke: ${ }_{13} \mathrm{C}$; Yale: A, K.

Joseph Hergesheimer. Yale: $39 \mathrm{C}, \mathrm{D}$.

Langston Hughes. Yale: A, large collection of $\mathrm{E}, \mathrm{K}$.

Grace Humphrey. Wellesley: 16C.

Aldous Huxley. Dartmouth: 102C (by and relating to)

Rufus M. Jones. Colby: 98C (first editions and reprints), $\mathrm{IE}$, several $\mathrm{L}, \mathrm{M}$.

James Joyce. Harvard: ${ }_{17} \mathrm{C}, m s$ of the Portrait of the Artist as a Young Man.

Ring Lardner. Harvard: $2 \mathrm{IC}$.

T. E. Lawrence. Dartmouth: $64 \mathrm{C}, \mathrm{K}$. 
William Ellery Leonard. Boston University: A.

Sinclair Lewis. Mount Holyoke: ${ }_{23} \mathrm{C}$; Yale: A, $10 \mathrm{E}$ (novels), $\mathrm{H}, \mathrm{K}$.

Vachel Lindsay. Harvard: $35 \mathrm{C},{ }_{17} \mathrm{~L}$; Wellesley: ${ }_{17} \mathrm{C}, 2 \mathrm{~L}$.

Amy Lowell. Harvard: $45 \mathrm{C}, \mathrm{B}$ (poems and articles in magazine form), ${ }_{4} \mathrm{E}, \mathrm{IIJ}_{\mathrm{I}} \mathrm{K}$; Wellesley: $19 \mathrm{C}, 3 \mathrm{~J}$.

Archibald MacLeish. Harvard: ${ }_{23} \mathrm{C},{ }_{4} \mathrm{E}$.

John Masefield. Harvard: D, 40E, many L; Wellesley: 29C, roL.

Edgar Lee Masters. Wellesley: 12C, rL.

Somerset Maugham. Yale: $50 \mathrm{C}, 22 \mathrm{E}$.

H. L. Mencken. Dartmouth: ${ }_{165} \mathrm{C}$ (by and relating to), $5 \mathrm{~J}, 35 \mathrm{~L}$.

Edna St. Vincent Millay. Brown: C (practically all); Colby: $20 \mathrm{C}, \mathrm{K}$; Middlebury: I6C, $\mathrm{IJ}, \mathrm{IL} ; W$ ellesley: $19 \mathrm{C}$.

Merrill Moore. Harvard: $9 \mathrm{C},{ }_{3} \mathrm{E}$.

Brookes More. Wellesley: 6C, IE, IJ, IL.

Charles Morgan. Yale: $9 \mathrm{C}$, $1 \mathrm{E}$.

Christopher Morley. Harvard: $58 \mathrm{C}$ and $\mathrm{K}$; Yale: A, $2 \mathrm{E}$; Wellesley: ${ }_{3} \mathrm{C},{ }_{4} \mathrm{~J}, \mathrm{IL}$.

Alfred Noyes. Wellesley: $12 \mathrm{C}, \mathrm{IJ}$.

Eugene O'Neill. Yale: A, many E and K.

Oliver Onions. Harvard: $4 \mathrm{IC}$.

Katherine Anne Porter. Mount Holyoke: A (except one).

Kenneth Roberts. Colby: 18C, several L, K; Dartmouth: 28C, IJ (deposit).

Edwin Arlington Robinson. Colby: $400 \mathrm{C}$ (by and about), ${ }_{15} \mathrm{E}$ (poems), $\mathrm{IH}_{\mathrm{H}}$ (Greek translations, unpublished), $300 \mathrm{~L}$ and $\mathrm{K}$, $\mathrm{N}, 200$ volumes from his library; Harvard: $110 \mathrm{C}, \mathrm{I} 400 \mathrm{~L}$; Middlebury: $22 \mathrm{C}$, 18L; Wellesley: 21 $\mathrm{C}, 5 \mathrm{~L} ;$ Williams: I $46 \mathrm{C},{ }_{7} \mathrm{E}$ and $\mathrm{J}, \mathrm{K}, 18 \mathrm{~L}, 3 \mathrm{~N}$; Yale: $\mathrm{A}$, $\mathrm{B}, \mathrm{K}, 5 \mathrm{OL}$.

Agnes Rothery. Wellesley: 8C.

Ruth Barr Sanborn. Radcliffe: A.

Carl Sandburg. Wellesley: $5 \mathrm{C}, \mathrm{IJ}$.

George Santayana. Dartmouth: ${ }_{13} \mathrm{C}$; Wellesley: $5 \mathrm{C},{ }_{4} \mathrm{~L}$.

Dallas Lore Sharp. Boston University: A.

Gertrude Stein. Yale: D, IE, 250J (with corrections), G (deposit), K.

John Steinbeck. Harvard: $59 \mathrm{C}, \mathrm{E}$ (unpublished), 16L; Mount Holyoke: ${ }_{13} \mathrm{C}$.

Ruth Suckow. Mount Holyoke: 8C.

Sara Teasdale. Wellesley: 16C, $2 \mathrm{~L}, 100$ books from library; Yale: D, many E and $\mathrm{L}$.

H. M. Tomlinson. Yale: ${ }_{125} \mathrm{C}, 50 \mathrm{E}, \mathrm{K}$.
Rebecca West. Mount Holyoke: ${ }_{4} \mathrm{C}$.

Thornton Wilder. Yale: A, IE, K.

Ben Ames Williams. Colby: $33 \mathrm{C}$, IE, several $\mathrm{L}, \mathrm{K}$.

Henry Williamson. Dartmouth: $40 \mathrm{C}$ (by and about), $\mathrm{IJ}, 20 \mathrm{~L}$.

Thomas Wolfe. Harvard: A, IE (Look Homeward, Angel), documents and L relating to Of Time and the River, mss of undergraduate plays.

Virginia Woolf. Harvard: Considerable C and E; Mount Holyoke: $26 \mathrm{C}$.

Elinor Wylie. Wellesley: $7 \mathrm{C}$.

Of the materials reported, nearly all came to their institutions by gift. Colby and Dartmouth have secured all but one of theirs in this manner. Middlebury, however, has bought all the books in her four collections. Mount Holyoke's growing accumulations also have been received by purchase. Brown, too, has bought and is buying all printed items by American poets for its famous Harris collection. Harvard has purchased one collection and part of another. Three of Yale's collections came "from various sources." In most instances, the exceptions being those at Mount Holyoke and the University of Vermont, the materials have been segregated.

The University of Maine raises several interesting points. One Maine library, it is reported from there, makes an effort to obtain for stack use editions not marked "first editions" on the verso of the title page. This is on the ground that books so marked, in the mind of the general public, are valuable and, therefore, are apt to be stolen. Specific questions are whether library collections of first editions should conform to the standards of the book collector and have uncut pages, dust jackets, and no library markings; whether librarians and scholars really should be actively concerned about first editions. One point not to be forgotten here is that later editions often vary in text from the first as is true in the notable case of Melville's Typee and 
that scholars often want to see first editions with the exact text as it went to press for the first printing.

Another point raised at Maine is "that the majority of books printed since 1870 will have a relatively short life-span compared to their predecessors." If, therefore, first editions are to be acquired, cannot writers, publishers, and librarians agree upon a better product of book making, to the end that at least a limited number of copies may be produced on durable paper for libraries and book collectors?

Practically all the collections reported have been secured for research purposes. Middlebury's reply regarding this, however, possibly indicates another aim: "Our main reason for collecting these modern authors is because they seem to us representative of the best today in modern American literature, and our Abernathy library is a library of American literature." Nearly all the libraries also are making additions to their collections.
A number of authors whose works are not represented in any New England collections were suggested by various librarians as worthy of being secured. Although only five librarians answered the question relating to this, the following writers were mentioned: Léonie Adams, Louis Adamic, James Truslow Adams, Hervey Allen, Sherwood Anderson, W. H. Auden, Charles A. Beard, Brian O. Donn-Byrne, Kenneth Burke, Van Wyck Brooks, Pearl S. Buck, Henry S. Canby, Mary Ellen Chase, Hart Crane, Cecil Day Lewis, Theodore Dreiser, E. M. Forster, Constance Holme, Robinson Jeffers, D. H. Lawrence, Ludwig Lewisohn, Katharine Mansfield, Lewis Mumford, George Jean Nathan, Donald C. Peattie, William Saroyan, the Sitwells, Upton Sinclair, Stephen Spender, Booth Tarkington, Carl Van Doren, Hendrik Willem van Loon, Wallace Stevens, Mary Webb, Edmund Wilson, A. Yvor Winters, Hugh Walpole, and William Carlos Williams.

\section{University Library Charging Systems}

\section{(Continued from page 53)}

there must even be a card involved, but the present authors lack the imagination to suggest a suitable substitute.

Since the problem is thus reduced to one of finding a suitable sorting device, possible solutions begin to present themselves; for example, a mere pencil mark placed on the bookcard would permit sorting by means of a photoelectric cell, or a small nonprotruding steel clip would allow for sorting by means of an electro-magnet. To these could be added other devices evolved from fundamental physical principles, but at this point the problem should be turned over to technicians who will probably have to be found outside the profession. The time for calling upon such technicians for assistance is long overdue. Some library supply houses have set up research bureaus, the interest and activity of which should be solicited. Expert council should be sought, and a satisfactory solution would be well worth the expenditure of the necessary funds. For this reason it is strongly urged that the Association of College and Reference Libraries take formal action, not to investigate the problem, but to seek a satisfactory solution by means of perfected mechanisms adaptable to the types of libraries involved. 